\title{
Improvement of Magnesium and Calcium Deficiency in Patients with Gastroesophageal Reflux Disease Associated with Undifferentiated Connective Tissue Disease
}

\author{
Iryna Romash ${ }^{*}$, Vasyl Mishchuk
}

\begin{abstract}
The objective of the research was to study the effectiveness of course application of magnesium and calciumcontaining drugs on the background of conventional therapy on the changes in the content of macronutrients in red blood cells and the activity of matrix metalloproteinase - 9 in the patients with a co-existence of undifferentiated connective tissue disease and gastroesophageal reflux disease.

Materials and Methods. All 75 patients with gastroesophageal reflux disease associated with undifferentiated connective tissue disease were divided into three groups: Group I included 25 patients who received Magne-B6 at a dose of 2 tablets 3 times a day in addition to the standard background therapy with "Panocid" at a dose of $40 \mathrm{mg}$ once a day; Group II comprised 25 patients who received "Ca-D3 Nycomed" at a dose of 1 tablet 3 times a day in addition to the standard background therapy; Group III included 25 patients who received a combination of "Magne-B6" and "Ca-D3 Nycomed" in addition to the standard background therapy.

Results. In Group I, the proposed complex therapy resulted in a significant increase in $\mathrm{Mg}^{2+}$ by $40.9 \%$. $\mathrm{Mg}^{2+}$ dynamics was less significant in Group II; this index reached the level of $17.9 \pm 2.04 \mu \mathrm{g} / \mathrm{g}(\mathrm{p}$ " $>0.05)$; in its turn, $\mathrm{Ca}^{2+}$ level increased to $80.6 \pm 2.12 \mu \mathrm{g} / \mathrm{g}(\mathrm{p} "<0.05)$ in these patients. $\mathrm{Mg}^{2+}$ and $\mathrm{Ca}^{2+}$ indices showed the most significant positive dynamics in Group III: $21.52 \pm 2.47 \mu \mathrm{g} / \mathrm{g}(\mathrm{p} "<0.05)$ and $102.7 \pm 1.37 \mu \mathrm{g} / \mathrm{g}$, respectively. After combination treatment, we traced the dynamics of changes in the level of matrix metalloproteinase - 9: it decreased by $39.45 \%$ in Group I, by $35.3 \%$ in Group II, by $53.18 \%$ in Group III and reached the level of $1689.266 \pm 14.89 \mathrm{pg} / \mathrm{ml}$, approaching the indicators of the control group.

Conclusions. Based on the data obtained, it can be argued that simultaneous addition of "Magne-B6" and "Ca-D3 Nikomed" to the standard therapy for gastroesophageal reflux disease in the patients with undifferentiated connective tissue disease contributed to a significant decrease in the level of matrix metalloproteinase-9 resulting in reduced degradation and increasing synthesis of new connective tissue components.
\end{abstract}

Keywords

gastroesophageal reflux disease; undifferentiated connective tissue dysplasia; matrix metalloproteinase-9; magnesium and calcium deficiency

Ivano-Frankivsk National Medical University, Ivano-Frankivsk, Ukraine

*Corresponding author: iromash@ifnmu.edu.ua

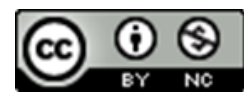

Copyright (C)Iryna Romash, Vasyl Mishchuk, 2019

\section{Problem statement and analysis of the latest research}

Micronutrients and macronutrients being cofactors of matrix metalloproteinases (MMP) play an im- portant role in the synthesis of the basic structural proteins of connective tissue [1]. In particular, $\mathrm{Mg}$ influences the activity of enzymes involved in the formation of collagen providing flexibility and elas- 
ticity to the connective tissue matrix [2]. Pyridoxine is also very important for the metabolic support of connective tissue function and stimulation of collagen formation $[3,4]$. Protein synthesis of connective tissue is slowed in case of both magnesium and pyridoxine deficiency [5]. Mg deficiency contributes to the increase in MMP activity and thus causes aggressive degradation of collagen fibers and loss of connective tissue strength. The abnormalities of tissue structure manifesting themselves as a decrease in the content of certain types of collagen or their ratio distortion are considered as connective tissue disease (CTD).

The probability of internal organ pathology increases in CTD. Gastrointestinal tract (GI) is one of the systems that are most often involved in the pathological process of undifferentiated connective tissue disease (UCTD), especially the esophagus. Cardiac insufficiency is one of UCTD manifestations and there is a direct relation between UCTD degree and the incidence of gastroesophageal reflux [6]. Over recent years, experimental works have also started to appear showing that magnesium deficiency may affect the development of gastroesophageal reflux disease (GERD). Smooth muscle contraction is known to underlie the regulation of vascular tone in general, and the balance of $\mathrm{Ca}^{2+}$ and $\mathrm{Mg}^{2+}$ ions [7] provides post-epithelial protection of the mucous membrane maintaining adequate blood flow and trophism of the esophageal submucous membrane. Therefore, the imbalance and/or deficiency of these ions are capable of disrupting the processes of neuromuscular transmission and muscles contraction which, in its turn, manifests in the form of gastroesophageal (GER) and duodenogastric (DGR) refluxes [8]. Decrease in magnesium concentration in the body contributes to a severer course of GERD and reduction in the quality of life [9].

The inhomogeneity of $\mathrm{Mg}^{2+}$ and $\mathrm{Ca}^{2+}$ distribution in different tissues of the body, its predominant content inside the cells complicate diagnose of their deficiency only by blood content. According to the literature data, a decrease in their content in blood serum occurs only in case of a clear deficiency of these ions. According to the scientific literature, the determination of magnesium and calcium in red blood cells is more informative in comparison with their determination in blood serum $[9,10]$.

Concurrently, the dynamics of $\mathrm{Mg}^{2+}, \mathrm{Ca}^{2+} \mathrm{lev}-$ els and the activity of matrix metalloproteinases under the influence of magnesium and calciumcontaining drugs have not been studied in the patients with GERD associated with UCTD.

The objective of the research was to study the effectiveness of course application of magnesium and calcium-containing drugs on the background of conventional therapy on the changes in the content of macronutrients in red blood cells and the activity of matrix metalloproteinase- 9 in the patients with a combination of UCTD and GERD.

\section{Materials and Methods}

The research was conducted at the Therapeutic Department No 2 of Ivano-Frankivsk Central City Clinical Hospital $(\mathrm{CCCH})$ and the University Clinic of the Ivano-Frankivsk National Medical University (IFNMU). The research included 120 patients. The study group consisted of 75 patients with GERD associated with UCTD. All the patients were divided into three subgroups depending on the proposed treatment regimen. The first group (Group I) included 25 patients who received Magne-B6 at a dose of 2 tablets 3 times a day in addition to the standard background therapy with Panocid at a dose of 40mg once a day. The second group (Group II) consisted of 25 patients who received Ca-D3 Nycomed at a dose of 1 tablet 3 times a day in addition to the standard background therapy. The third group (Group III) included 25 patients who received a combination of Magne-B6 and Ca-D3 Nycomed in addition to the standard background therapy. The control group consisted of 25 patients with GERD without UCTD symptoms. Twenty apparently healthy individuals were also examined.

The concentration of MMP-9 in blood serum was determined in all the examined subjects included into the research by the immune-enzyme method using Immuno Chem-2100 Microplate Reader with the use of the RayBiotech Human MMP-9 Ensyme Immunoassay Kit (USA) and was 
stated in $\mathrm{pg} / \mathrm{ml}$. Atomic absorption spectrophotometry (AAS) was applied with the use of C-115PK instrument in order to study the content of $\mathrm{Mg}^{2+}$ and $\mathrm{Ca}^{2+}$ in the packed red blood cells. The method is based on the diffusion of a mineralized agent solution in air-acetylene flame and the measurement of the resonant absorption of atoms of the studied element. All examinations were performed before the treatment and 1 month after the treatment.

Statistical processing of the obtained results was performed using the STATISTICA 7.0. and the statistical package of the Microsoft Excel 2016 program. The significance of the obtained results was confirmed on the basis of the calculation of Student's coefficient. Correlation analysis was conducted according to Pearson correlation coefficient. The quantitative characteristics were described using arithmetic mean $(\mathrm{M})$, standard error $( \pm \mathrm{m})$, and interquartile range: lower - higher quartile (LQHQ).

When working with patients, we adhered to the ethical principles of the Helsinki Declaration of World Medical Association adopted in 1964 (amended in 2000), the Charter of the Ukrainian Association for Bioethics and Good Clinical Practice (GCP) Standards (1992), in accordance with the requirements and standards of the CCI GCP (2002), the Model Regulations of the Ethics Committee approved by the Ministry of Health of Ukraine No 66 dated 13.02.2006. Before being included into the research, all the patients signed a voluntary informed consent to participate in the research and were fully aware of the methods and the scope of the research. The research was approved by the Bioethics Committee of the IFNMU.

\section{Results}

The indices of magnesium and calcium content in the patients with GERD associated with UCTD before the treatment are presented in Table 1.

According to the data presented in Table $1, \mathrm{Mg}^{2+}$ level in red blood cells was 1.3 times lower in the patients of the study group in comparison with the patients without comorbid pathology and 1.6 times lower as compared to healthy individuals $\left(\mathrm{p}^{\wedge}<0.05\right.$; $\left.\mathrm{p}^{*}<0.05\right)$. The level of $\mathrm{Ca}^{2+}$ in red blood cells in the patients with GERD associated with UCTD was 1.68 times lower as compared to the patients, who were diagnosed with GERD without concomitant pathology and 1.8 times lower in comparison with healthy individuals $\left(\mathrm{p}^{\wedge}<0.05 ; \mathrm{p}^{*}<0.05\right)$. MMP-9 content in such patients constituted 3608.5 \pm 77.43 , $1561.389 \pm 71.77$ and $1442.84 \pm 87.80 \mathrm{pg} / \mathrm{ml}$ on average, respectively $\left(\mathrm{p}^{\wedge}<0.05 ; \mathrm{p}^{*}<0.05\right)$.

Therefore, the obtained data confirmed that magnesium and calcium deficiency was noted in case of GERD as an independent disease as well as in case of its combination with UCTD causing an increase in MMP-9 activity. Moreover, severer alteration of $\mathrm{Mg}^{2+}$ and $\mathrm{Ca}^{2+}$ levels and MMP-9 activity occurred in the patients with GERD associated with UCTD and required the inclusion of drugs capable of influencing the detected changes in the complex therapy for this comorbid condition.

The dynamics of $\mathrm{Mg}^{2+}$ and $\mathrm{Ca}^{2+}$ content in red blood cells under the influence of the proposed complex therapy is presented in Fig. 1 and Fig. 2.

According to the data presented in Fig. 1, the inclusion of Magne-B6 in the conventional therapy in the patients of Group I promoted a more significant increase in $\mathrm{Mg}^{2+}$ in red blood cells by $40.9 \%$ from $14.123 \pm 1.362 \mu \mathrm{g} / \mathrm{g}$ to $19.4 \pm 1.239 \mu \mathrm{g} / \mathrm{g}$, and it was higher by $1.45 \mu \mathrm{g} / \mathrm{g}$ as compared to the control group, although it did not reach the level of healthy individuals. $\mathrm{Ca}^{2+}$ level in red blood cells did not change significantly in the patients of this group, although it increased to $61.3 \pm 4.16 \mu \mathrm{g} / \mathrm{g}$ (Fig. 2). $\mathrm{Mg}^{2+}$ dynamics was less significant in the patients of Group II, who received Ca-D3 Nycomed in addition to the background therapy; this index reached the level of $17.9 \pm 2.04 \mu \mathrm{g} / \mathrm{g}$ ( $\mathrm{p} ">0.05)$. In its turn, $\mathrm{Ca}^{2+}$ level significantly increased to $80.6 \pm 2.12 \mu \mathrm{g} / \mathrm{g}(\mathrm{p} "<0.05)$ in these patients in comparison with the data before the treatment, but it still remained lower by $11.5 \%$ in comparison with the control group and by $18.9 \%$ as compared to healthy individuals. $\mathrm{Mg}^{2+}$ and $\mathrm{Ca}^{2+}$ indices showed the most significant positive dynamics in Group III, where Magne-B6 and Ca-D3 Nycomed were included in the background therapy. In particular, magnesium content reached $21.52 \pm 2.47 \mu \mathrm{g} / \mathrm{g}$ 
Table 1. $\mathrm{Mg}^{2+}$ and $\mathrm{Ca}^{2+}$ content in red blood cells and MMP-9 in the blood plasma of the examined patients $(\mathrm{M} \pm \mathrm{m})$.

\begin{tabular}{|c|c|c|c|}
\hline & $\begin{array}{c}\text { Study group } \\
\text { GERD + UCTD } \\
n=75 \\
\text { before the treatment }\end{array}$ & $\begin{array}{l}\text { Control group, } \\
\qquad \begin{array}{c}\text { (GERD) } \\
n=25\end{array}\end{array}$ & $\begin{array}{l}\text { Healthy individuals, } \\
\qquad \mathrm{n}=20\end{array}$ \\
\hline $\mathrm{Mg}^{2+}(\mu \mathrm{g} / \mathrm{g})$ & $14.123 \pm 1.362 * \wedge$ & $18.450 \pm 1.419$ & $21.9 \pm 2.739$ \\
\hline $\mathrm{Ca}^{2+}(\mu \mathrm{g} / \mathrm{g})$ & $53.323 \pm 1.089 * \wedge$ & $89.862 \pm 0.789$ & $99.5 \pm 0.189$ \\
\hline MMP-9 pg/ml & $3608.5 \pm 77.43 * \wedge$ & $1561.389 \pm 71.77$ & $1442.84 \pm 87.80$ \\
\hline
\end{tabular}

Notes:

* $-(\mathrm{p}<0.05)$ the data are reliable in comparison with the indices of healthy individuals;

$\wedge-(\mathrm{p}<0.05)$ the data are reliable in comparison with the control group.



Figure 1. Dynamics of $\mathrm{Mg}^{2+}$ content in red blood cells in the examined patients under the influence of concurrent correction.

Note: $"-(\mathrm{p}<0.05)$ the data are reliable with regard to the indices before and after the treatment.

increasing by 1.16 times as compared to the control group and approaching the indices of group with healthy individuals $(\mathrm{p} "<0.05) . \mathrm{Ca}^{2+}$ index also increased by 1.9 times on average reaching $102.7 \pm 1.37 \mu \mathrm{g} / \mathrm{g}$. This index increased by $12.5 \%$ on average in comparison with the control group and almost reached the indices of group with healthy individuals $(\mathrm{p} "<0.05)$.

The initial data on the level of MMP-9 in the patients with UCTD and GERD as well as GERD as an independent pathology before the inclusion in the treatment are presented in Fig. 3. According to the presented data, MMP-9 concentration in the patients with combined pathology was 2.5 times higher than in healthy individuals and 1.9 times higher in comparison with the patients with GERD without connective tissue lesions. While MMP-9 level in healthy individuals ranged from $1442.84 \pm 87.80$, Me of this index constituted 3399.283 among the patients with comorbid pathol- 


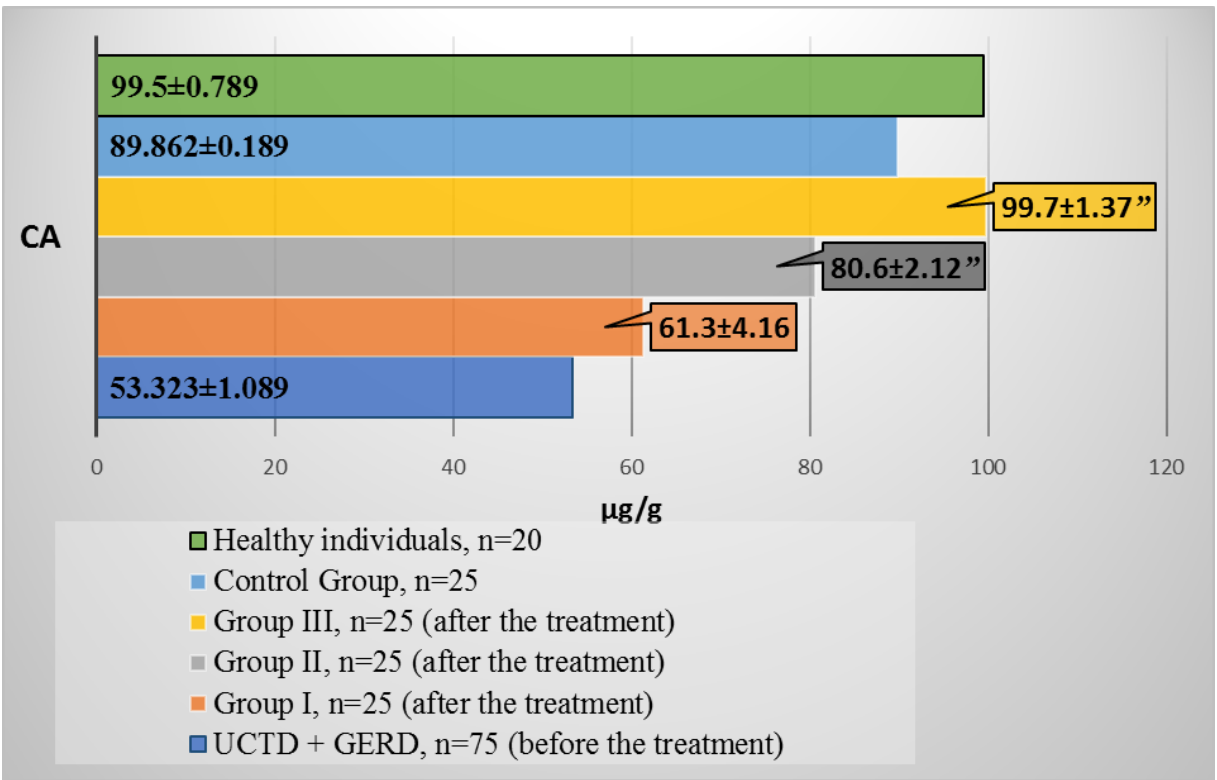

Figure 2. Dynamics of $\mathrm{Ca}^{2+}$ content in red blood cells in the examined patients under the influence of corrective treatment.

Note: $"-(\mathrm{p}<0.05)$ the data are reliable with regard to the indices before and after the treatment.

ogy; Mo was 3091.61 with interquartile range (LQHQ) constituting 3081.201-4039.798 pg/ml. Me was 1561.389; Mo constituted 1602.151; LQ-HQ=1014.925-1973.303 in the group of the patients with GERD without connective tissue lesions.

A correlation analysis before the treatment found the existence of a strong negative relations between MMP-9 levels and Mg concentration and MMP-9 and $\mathrm{Ca}$ in red blood cells. This confirmed the data that $\mathrm{Mg}^{2+}$ deficiency led to an increase in MMP-9 collagenase activity $[11,12]$.

We monitored the dynamics of changes in MMP9 level after the provided combination treatment with the inclusion of the methods of trace element metabolism correction in the background therapy (Table 2, Fig. 4). The average value of this index in the patients of Group I decreased by $39.45 \%$ in comparison with the initial data reaching $2184.835 \pm 36.12 \mathrm{pg} / \mathrm{ml}(\mathrm{p} "<0.05)$ and remaining 1.3 times higher in comparison with the same index of the control group and 1.5 times higher than the average value of this index in healthy individuals (Fig. 4). The average value of MMP-9 in the patients of Group II decreased by $35.3 \%$ as compared to the initial data and reached $2335.018 \pm 27.34$ $\mathrm{pg} / \mathrm{ml}(\mathrm{p}$ " $<0.05)$. According to the presented data, the improvement of $\mathrm{Mg}^{2+}$ deficiency reduced MMP9 concentration by $4.16 \%$ more on average in comparison with the introduction of $\mathrm{Ca}^{2+}$. MMP-9 level decreased by $53.18 \%$ in comparison with the initial data and amounted to $1689.266 \pm 14.89 \mathrm{pg} / \mathrm{ml}$ with an interquartile range of 1483.781-1990.542 approaching the level of the control group in the patients of Group III who underwent the improvement of $\mathrm{Mg}^{2+}$ and $\mathrm{Ca}^{2+}$ levels alongside with the standard background therapy. Thus, according to the obtained data, it can be argued that simultaneous inclusion of both drugs in the standard therapy for GERD in the patients with UCTD had a more significant effect on MMP-9 index.

\section{Discussion}

The results of the research indicated that GERD as an independent disease and in combination with UCTD manifests as diselementosis thereby increasing the activity of MMP-9. Moreover, more significant abnormalities of $\mathrm{Mg}^{2+}$ and $\mathrm{Ca}^{2+}$ levels in red blood cells and MMP-9 activity were noted in comorbidity requiring the inclusion of the drugs 


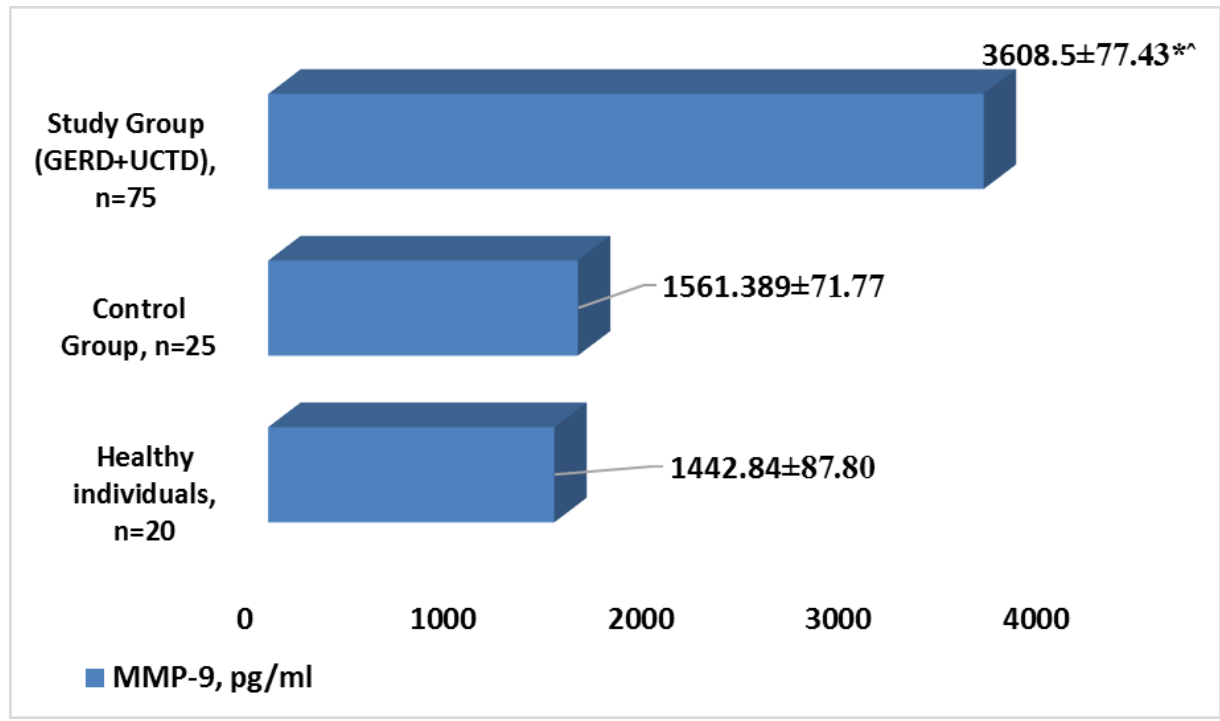

\section{Notes:}

Figure 3. MMP-9 level in the patients before the treatment.

* $-(\mathrm{p}<0.05)$ the data are reliable in comparison with the indices of healthy individuals;

$\wedge_{-}(\mathrm{p}<0.05)$ the data are reliable between the study groups.

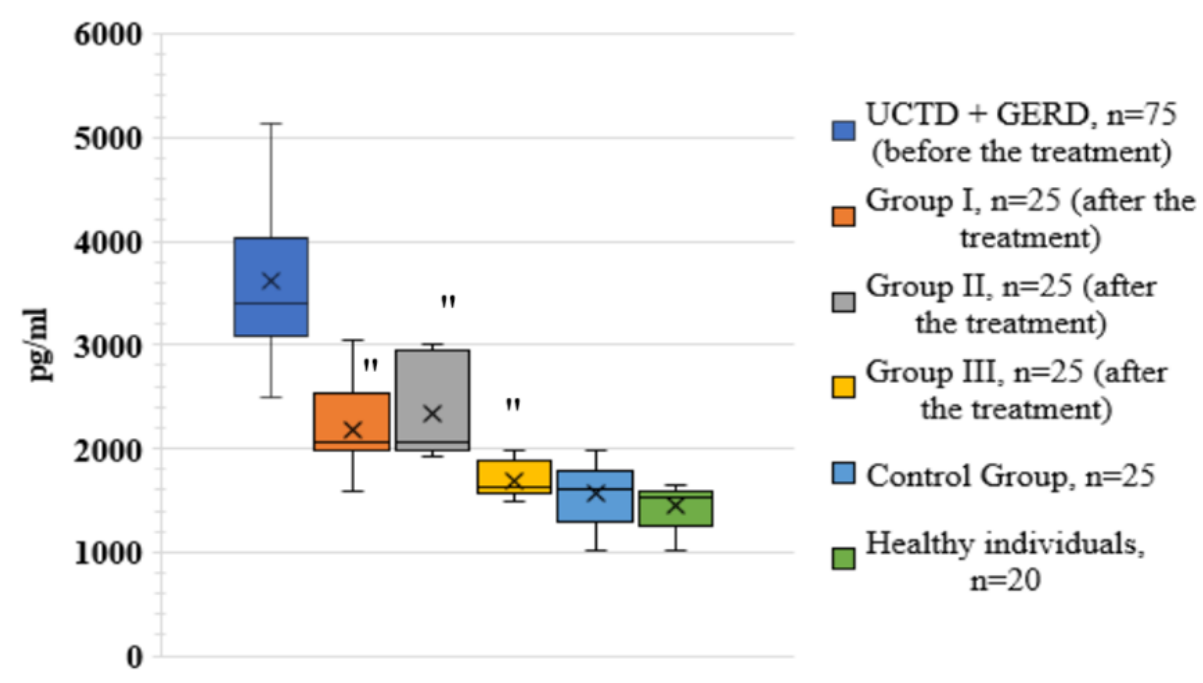

Figure 4. Interquartile ranges of MMP-9 in the examined patients after the treatment. Note: " $-(\mathrm{p}<0.05)$ the data are reliable with regard to the indices before and after the treatment.

capable of influencing changes detected in combination therapy for such comorbidity. The obtained data were consistent with the results obtained by other authors [13,14]. According to the research of G.I. Nechaeva and co-authors [5], magnesium deficiency was noted in $47.84 \%$ of the patients and calcium deficiency was detected in $64.1 \%$ of the patients with connective tissue disease. $\mathrm{Mg}^{2+}$ deficiency leads to an increase in MMP-9 collagenase activity, and according to the scientific data, it accelerates the degradation of the structural components of intracellular matrix, primarily collagen. This effect is apparently related to the inhibitory effect of magnesium ions on MMP by competitive binding of divalent cations in their active center. According to Ahvazi B. (2004) et al., insufficient content of $\mathrm{Mg}^{2+}$ in the body alongside with the increased expression of collagenases reduces the activity of 
Table 2. Influence of combination therapy with the inclusion of magnesium and calcium on MMP-9 level.

\begin{tabular}{c|ccc}
\hline \multirow{2}{*}{ The examined group } & \multicolumn{3}{c}{ MMP-9 $(\mathrm{pg} / \mathrm{ml})$} \\
\cline { 2 - 4 } Group I, n=25 & Me $\pm \mathrm{m}$ & Mo & LQ-HQ \\
\hline Before the treatment, n=75 & $21808.5 \pm 77.43$ & 3399.283 & $2501.5-5132.402$ \\
After the treatment Group II, n=25 & $2335.018 \pm 27.34 ”$ & 2067.887 & $1590.203-3039.798$ \\
Group III, n=25 & $1689.266 \pm 14.89 ”$ & 1627.092 & $1483.781-1990.542$ \\
Control group, n=25 & $1561.389 \pm 71.77$ & 1602.151 & $1014.925-1973.303$ \\
Healthy individuals, n=20 & $1442.84 \pm 87.80$ & 1590.203 & $1014.925-1655.609$ \\
\hline
\end{tabular}

Note: " $-(\mathrm{p}<0.05)$ the data are reliable with regard to the indices before and after the treatment.

elastase leading to an increase in the concentration of flexible elastin fibers. $\mathrm{Ca}^{2+}$ has a significant effect on elastin fibers as well; its sufficient level helps stabilize microfibril structure. Elastin chains are joined by transglutaminase activated by $\mathrm{Ca}^{2+}$ and inhibited by $\mathrm{Mg}^{2+}[11,12] . \mathrm{Mg}^{2+}$ can inhibit copper-dependent lysyl oxidase (LOX). Therefore, the occurrence of "pathological" lateral sutures of collagen and elastin chains is possible in case of $\mathrm{Mg}^{2+}$ deficiency resulting in connective tissue granularization in case of increased MMP activity. Thus, the most likely scheme of $\mathrm{Mg}^{2+}$ and $\mathrm{Ca}^{2+}$ deficiency to influence the connective tissue is to enhance the destruction of collagen and elastin fibers as well as to break the bond between them. Therefore, the prevention of appearing new lateral sutures requires special attention by providing a sufficient concentration of $\mathrm{Mg}^{2+}$ and $\mathrm{Ca}^{2+}$ in the body since the suture appearance leads to an emergence of pathological connective tissue, whereas the sufficient concentration of $\mathrm{Mg}^{2+}$ and $\mathrm{Ca}^{2+}$ decreases the activity of PPM-9, degradation, and increases the synthesis of new collagen molecules, which was confirmed in our research.

\section{Conclusions}

Based on the data obtained, it can be argued that simultaneous addition of "Magne-B6" and "Ca-D3 Nikomed" to the standard therapy for gastroesophageal reflux disease in the patients with NDST contributed to a significant decrease in the level of MMP-9 resulting in reduced degradation and increasing synthesis of new connective tissue components.

\section{References}

[1] Shilov AM, Melnik MV, Sviridova AYu. Displaziya soyedinitelnoy tkani i defitsit magniya. Farmateka. 2010; 20(213): 35-38.

[2] Blancquaert L, Vervaet C, Derave W. Predicting and Testing Bioavailability of Magnesium Supplements. Nutrients. 2019;11(7):E1663. DOI: https: //doi.org/10.3390/nu11071663

[PMid:31330811 PMCid:PMC6683096]

[3] Faizullin OV, Bezkrovna KS, Shulga LI. Functional interaction of the elemental balance in the human body and the digestive system. Zb. nauk. prats spivrobit. NMAPO imeni P. L. Shupyka. 2019;33:63-73. [Published in Ukrainian].

[4] Prudenko MYu, Bodnia AA, Yarmysh NV. Biolohichna rol kaltsiiu ta tsynku $v$ rehuliatsii funktsii y rozvytku zakhvoriuvan systemy travlennia. Aktualnyye problemy eksperimentalnoy i klinicheskoy biokhimiyi: materialy VI Mezhvuz. nauch.-prakt. konf. s mezhdunar uchastiyem. Kharkiv: KhNMU; c2017. 91-92.

[5] Nechayeva GI, Drokina OV, Druk IV et al. Main approaches in treatment of patients with 
connecting tissues dysplasia. Attending Doctor. 2014;8:54-56. [Published in Russian]

[6] Gnusaev SF, Apenchenko YuS, Rozov DN. Vzaimosvyaz gastroezofagealnogo reflyuksa i priznakov displaziyi soyedinitelnoy tkani $u$ detey i podrostkov. Posobiye dlya vrachey. Moscow. c2004. 20p.

[7] Akata T. Cellular and molecular mechanisms regulating vascular tone. Part 1: basic mechanisms controlling cytosolic $\mathrm{Ca} 2+$ concentration and the $\mathrm{Ca} 2+$ "dependent regulation of vascular tone. J Anesth. 2007;21:220231. DOI: https://doi.org/10.1007/ s00540-006-0487-5 [PMid:17458652]

[8] Bychkov MA, Yakhnytska MM. Osoblyvosti vmistu elektrolitiv u shlunkovomu soku khvorykh na hastroezofahalnu refleksnu khvorobu. Ukraine. Nation's Health. 2016;12(37'38):16-18.

[9] Marushko IuV, Asonov AO, Hyschak TV. The role of magnesium in humans and the effect of reduced magnesium on the quality of life of children with gastro esophageal reflux disease. Sovremennaya Pediatriya. 2019;1(97):124-130. [Published in Ukrainian] DOI: https://doi.org/10 . $15574 /$ SP . 2019.97.124

[10] Kens KA, Lukyanenko NS, Nakonechnyi AY et al. Substantiation of treatment tactics in young children with congenital malformations associated with undifferentiated connective tissue dysplasia. Paediatric Surgery. 2017; 4(57):8084. [Published in Ukrainian] DOI: https: / / doi.org/10.15574/PS.2017.57.80

[11] Ahvazi B, Boeshans KM, Rastinejad F. The emerging structural understanding of transglutaminase 3. J Struct Biol. 2004;147(2):200207. DOI: https: / / doi .org/10.1016/ j.jsb.2004.03.009 [PMid:15193648]

[12] Ahvazi B, Boeshans KM, Idler W et al. Roles of calcium ions in the activation and activity of the transglutaminase 3 enzyme. J Biol Chem. 2003;278(26):23834-23841. DOI: https : / / doi.org/10.1074/jbc.M301162200 [PMid:12679341]

[13] Tvorogova TM, Vorobyeva AS. Nedifferentsiirovannaya displaziya soyedinitelnoy tkani s pozitsiyi diselementoza u detey i podrostkov. RMZh. 2012;4:12-15.

[14] Ismail AA, Ismailn NA. Magnesium: A mineral essential for health yet generally underestimated or even ignored. J Nutr Food Sci. 2016;6:4. DOI: https://doi .org/ $10.4172 / 2155-9600.1000523$

Received: 2019-09-30

Revised: 2019-10-24

Accepted: 2019-10-29 